\title{
A Land-Based and Spatial Assessment of Local Food Capacity in Northern Idaho, USA
}

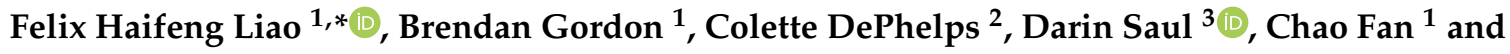 \\ Wenlong Feng 4 \\ 1 Department of Geography, University of Idaho, Moscow, ID 83844-3021, USA \\ 2 University of Idaho Extension, Northern District, College of Agricultural and Life Sciences, \\ University of Idaho, Moscow, ID 83844-3021, USA \\ 3 College of Agricultural and Life Sciences, University of Idaho, Moscow, ID 83844-3021, USA \\ 4 Department of Chemistry and Environmental Science, New Jersey Institute of Technology, \\ Newark, NJ 07102, USA \\ * Correspondence: hliao@uidaho.edu
}

Received: 1 July 2019; Accepted: 30 July 2019; Published: 4 August 2019

\begin{abstract}
Across the United States, there has been a growing interest in local food production, which provides an alternative way to increase self-sufficiency and support greater well-being and food security at the community level. This study focused on the Northern Panhandle region of Idaho, where opportunities derived from the local food movement have emerged in several resort and college towns. This research integrated spatial analysis and modeling in a geographic information system (GIS) environment and a linear-programming (LP) optimization approach to identify, quantify, and map these potential opportunities. The obtained results show that existing local food producers are located in the urban fringe and on productive cropland. The foodshed model further suggests that Northern Idaho has enough farmland to feed its whole population within an average distance of $49 \mathrm{~km}$ or 31 miles. An alternative land use scenario was explored that involves removing marginal cropland with high soil erodibility from commodity cropping to improve the ecological benefits of local food production. The results of the study, including nuanced evidence of growing demand for local-food products, the existence of enough cropland capacity to meet demand, and potential environmental benefits, are quite encouraging to local food advocates in Northern Idaho and other areas and demonstrate the utility of land-based foodshed analysis.
\end{abstract}

Keywords: geographic information systems (GIS); land use planning; foodshed model; local food systems; spatial analysis and modeling; production capacity

\section{Introduction}

In the United States, market interest in locally-grown food has increased [1]. According to one Congressional report, $7.8 \%$ of U.S. farms sold food through local food marketing channels from 2002 to 2007 , and the number of farms with local direct-to-consumer food sales increased by $32 \%$; this growth subsequently continued by $6 \%$ during 2007-2012 in the aftermath of the economic recession [1]. The literature typically defines "local food" as foods sold directly by farms to consumers, e.g., via farmers markets or roadside stands, or through intermediate marketing channels such as grocery stores and restaurants [1,2]. The growing demand for local food provides an important opportunity for small farms to increase their income [2]. The sales of retail "organic" food, especially fruits and vegetables, have similarly boomed from $\$ 17$ billion in 2006 to $\$ 40$ billion in 2016 [3]. Small farms tend to be heavily reliant on local sales; farms with gross cash farm income below $\$ 75,000$ accounted for $85 \%$ of all farms selling locally [1]. In addition, in light of the growing demand and a desire for healthier 
food diets, the successful marketing of local produce enables it to command a price premium over conventional produce.

The local food movement is also driven by broader concerns with respect to food security, nutrition, and sustainable community development. Across the United States, local food systems typically deliver smaller amounts of crops to local market centers where they are able to compete with conventional large-scale, long-distance agriculture and enhance the self-reliance of local food systems. However, because of the relative fragility of family farms, planning of the American food system has focused on strengthening the capacities of smaller-scale, often family-based, local food systems [4,5]. Small-acreage farms are of particular concern from a food system planning perspective and have also been studied in the context of rapid urbanization [6].

The question of how to increase food security and community wellbeing may find an answer in local food. An examination of the "foodsheds" of New York state indicated that local food could conceivably supply $69 \%$ of the food needs of the population of New York on an area of 2.7 million ha, or 6.7 million acres [7]. Other studies suggested potential for feeding populations with the surrounding farmland, including Galzki, Mulla, \& Peters [8], which, building on the foodshed methodology of Peters et al. [9], found that southeastern Minnesota, with its prime agricultural land, requires relatively small-size foodsheds to supply each of its larger cities and towns such as Rochester. Dundar, Costello, \& McGarvey [10] used a robust optimization model to calculate that the population of Boone County, Missouri, numbering 170,000, could be supported on its farmland. Overall, a meta-analysis of foodshed analyses found a "significant opportunity for food system re-localization across North America" [11], and a nationwide analysis finds that local food systems could provide all of the food needs of most areas of the United States, with the exception of high-density population centers such as the northeastern megalopolis or southern California [12]. Foodshed maps and related land-based assessments are not only of great help for leaders of local food movements in the United States, but also are widely used internationally [13]. For example, Karg et al. [14] found that although food provided within the city region assisted the provision of fresh perishable crops, a larger geographical diversity of foodsheds appeared to strengthen the resilience of local food systems in West Africa. In Europe, drawing upon the concept of urban resilience, foodshed maps were constructed to help policymakers develop the food self-sufficiency scenario in the cities of London, Berlin, Milan and Rotterdam [15]. However, with a few exceptions [8,16], little is known about the additional ecological benefits derived from local food production, especially those deriving from land use change. Beyond areas surrounding larger metropolitan regions, more work is also needed to better understand agricultural land capacity in proximity to fast-growing resort or college towns.

In this work, considering the case of Northern Idaho, foodshed models were operationalized to assess agricultural capacity while addressing locally important ecological issues such as soil erosion. Besides the baseline theoretical scenario, an alternative scenario was explored by considering key environmental concerns in Northern Idaho including the Palouse region. Moreover, the study echoes recent efforts to bridge the gap between theoretical foodshed analysis and the reality of the local food movement. As shown in Galzki et al. [17], the theoretical foodshed would be better calibrated using those data that can represent real-world situations, e.g., survey data that can represent food dietary habits in different regions. In this study, we employed a logistic regression analysis to better understand the current spatial distribution and spatial determinants of local food production. Furthermore, we integrated a variety of data sources including land use, soil, diet, and population distribution, to estimate and map the potential spatial extent of local foodsheds in the context of the Mountain West and in areas centered on college and resort towns, which may provide a useful comparison to cases in other areas. 


\section{Materials and Methods}

\subsection{Study Region}

This study focuses on Northern Idaho, often referred to as the Idaho Panhandle, which is a fairly thin strip of land in the Inland Pacific Northwest of the United States. With a total population of approximately 317,752 (based on US Census Bureau's 2010 decennial census), it is very mountainous and heavily forested, with some areas of prime agricultural land. In general, Northern Idaho's economy has been transitioning from natural resources (e.g., logging and mining) to services (e.g., recreation and tourism) and technologies known for recent growth in the so-called "amenity business" [18], and the total number of jobs in the region's accommodation and food services sector increased by more than 20\% during 2012-2017, which was higher than job growth in other sectors [19]. The agricultural land use in Northern Idaho greatly depends on the availability of good soil and water (Figure 1). The majority of the farmland is concentrated in a strip extending along areas close to the cities of Moscow and Lewiston, which is the Idaho portion of an area known as the Palouse region. Common crops in this area include winter wheat, peas, and lentils. The main transportation route through Northern Idaho is U.S. Highway 95, which runs from the Canadian border to southern Idaho. Coeur d'Alene, in Kootenai County, is the largest city in the region and sits adjacent to the fertile farming area referred to as the Rathdrum Prairie (Figure 1).

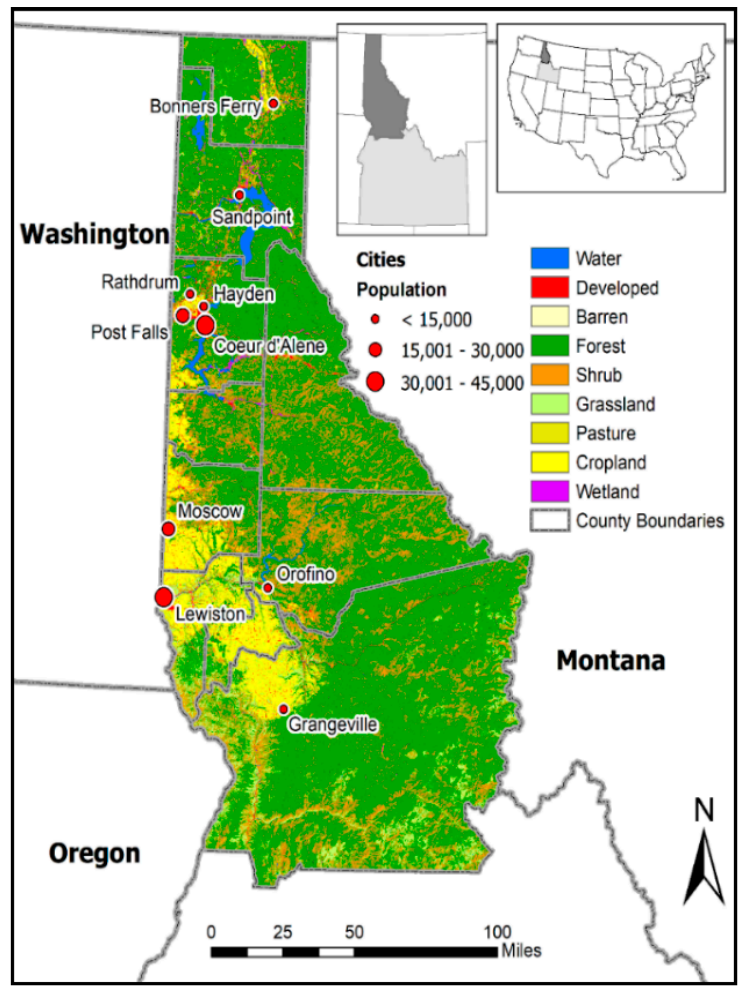

Figure 1. The Northern Idaho region consisting of 10 counties, located in the Mountain West of USA.

According to statistics from the 2017 USDA Census, the number of small farms less than 10 acres, increased by 146\% from 2007 to 2017 in the 10-county study region of Northern Idaho (Table 1). Moscow, home of the University of Idaho, and the resort town of Sandpoint both feature burgeoning farmers' markets. These markets are vital venues for the selling and buying of locally produced food, which is indicative of the increasing local food production in rural areas such as Latah and Bonner counties. In Idaho, local sales of food and food products were estimated to account for $3.8 \%$ of total state output and contributed $\$ 5$ billion in 2013. In contrast, the export-oriented production of agricultural production and food processing generated over $\$ 27.2$ billion during the same period. 
Economists suggested that local food in Idaho contributes $70 \%$ less to the state's economic output in comparison with exports [20]. Despite their smaller economic contribution as compared to export oriented agriculture, local food movements have gained strong momentum in Northern Idaho [21]. As of 2019, there were 17 active farmers markets in North Idaho [22] and a growing number of food establishments self-identifying as "farm-to-table" or "local food" restaurants.

Table 1. Number of farms per year by size in Northern Idaho $(\mathrm{N}=40)$.

\begin{tabular}{ccccccc}
\hline Size of Farms & $\mathbf{2 0 0 7}$ & $\mathbf{2 0 1 2}$ & $\mathbf{2 0 1 7}$ & $\mathbf{2 0 0 7 - 2 0 1 2}$ & $\mathbf{2 0 1 2 - 2 0 1 7}$ & $\mathbf{2 0 0 7 - 2 0 1 7}$ \\
\hline 1 acre to 9 acre & 416 & 527 & 1026 & $26.68 \%$ & $94.69 \%$ & $146.63 \%$ \\
$10-49$ acres & 1541 & 1386 & 2072 & $-10.06 \%$ & $49.49 \%$ & $34.46 \%$ \\
$50-179$ acres & 1376 & 1308 & 1247 & $-4.94 \%$ & $-4.66 \%$ & $-9.38 \%$ \\
$180-499$ acres & 832 & 822 & 596 & $-1.20 \%$ & $-27.49 \%$ & $-28.37 \%$ \\
$500-999$ acres & 340 & 315 & 272 & $-7.35 \%$ & $-13.65 \%$ & $-20.00 \%$ \\
1000 acres & 515 & 518 & 461 & $0.58 \%$ & $-11.00 \%$ & $-10.49 \%$ \\
\hline
\end{tabular}

Source: Agricultural census 2007, 2012, 2017.

\subsection{Data Preparation}

Related to this study, an intermediated retail grocery and restaurant buyer web-based survey was conducted in 2015. An initial sampling frame of retail grocery stores and restaurants was procured through InfoUSA and supplemented by internet searches and printed marketing literature. Email invitations to participate in the survey were sent directly to 198 retail grocers and 274 restaurants. Invitations to the survey were also sent to regional local food and small farm email listservs and through Facebook posts. Eighty-five complete responses were obtained from retail grocers and restaurants located in urban and rural communities across the state of Idaho, among which 40 respondents (or $47 \%$ ) were from Northern Idaho. The survey asked buyers to supply key information with respect to food products in demand. Questions on the survey polled buyers on their preferences on how they would have their food products sourced.

The theoretical foodshed analysis entails an estimation of the maximum demand for local food in the region. Using methods derived from Peters et. al. and others [11], the food needs of the average person per year were estimated by drawing upon the USDA ideal diet. Following previous seminal work done by Peters [9] and Galzki [8], a complete diet based on the food guide pyramid recommendations was used. The diet consisted of $170 \mathrm{~g}$ (or $6 \mathrm{oz}$ ) of meat per person per day, with $40 \%$ of total calories coming from fat [8].

The concept of human nutritional equivalent (HNE) is employed in the foodshed models, as suggested by Peters and others [9]. The constituents of the HNE include foods derived from annually cultivated land ( $\mathrm{HNEa}$ ) and foods grown on perennial cropland or pasture land (HNEp). The ideal diet was further derived from a list of crops (see Table 2) that can be grown or supported by agricultural land specific to the biophysical conditions in Northern Idaho. The list was also adjusted using data from the survey mentioned previously and expert input about crops that could be grown in the study region, as well as the information gathered from related local-food programs through the Idaho State Department of Agriculture, such as the Idaho Preferred program (Table 2). Different categories of agricultural products were considered, namely vegetables, fruits, meat, dairy, eggs, grains/field crops, and others.

Crop yield data on each commodity that make up the HNE were collected through recent five-year National Agriculture Statistics Service (NASS) and their Quick Stats program (https:/quickstats.nass. usda.gov/) that were made available through USDA. Yield data were adjusted by also considering the yield data in Washington State. Furthermore, products such as eggs, beef, and others derived from livestock were converted into an equivalent amount of feed crops [23]. Notably, they did not only include pasture needed to raise animals, but also annually cultivated land needed to grow feed crops. Therefore, meat and dairy products contribute to both the cultivated and pasture portions of 
the foodshed [9]. Like other foodshed studies [24], we made adjustments to take into consideration inedible portions of agricultural commodities and processing losses in the model.

Table 2. Representative crops used to determine production capacity

\begin{tabular}{cccc}
\hline Vegetables & Fruits & Meat, Dairy, Eggs & Grains/Field Crops/Others \\
\hline Asparagus & Apples & Beef & Wheat \\
Carrots & Blackberries & Pork & Barley \\
Cucumbers & Blueberries & Chicken & Corn for grain \\
Dry beans & Cherries & Chicken eggs & Oats \\
Dry peas \&/or lentils & Grapes & Cow milk & Forage \\
Garlic & Peaches & Cheese & Sugar beets \\
Green beans & Strawberries & & Canola oil \\
Greens bunched & & & Sunflower seeds \\
Greens, salad & & Nuts \\
Lettuce, head & & \\
Onions & & \\
Peas, green & & \\
Peppers & & \\
Potatoes & & \\
Squash, summer & & \\
Sweet corn & & \\
Tomatoes & & \\
\hline
\end{tabular}

Sources: Idaho preferred https://idahopreferred.com/, buyer survey, and experts' inputs.

Land use data was derived from the national land cover database (NLCD) with $30 \times 30 \mathrm{~m}$ resolution $[23,24]$. In Northern Idaho, NLCD statistics indicate that there were 369,953 ha (or 914,172 acres) of cropland and 6104 ha (15,084 acres) of pasture as of 2011 (see Figure 2). In contrast to other cases, our study region has a relatively limited amount of pasture cropland. Current dryland farming in the region mostly produces wheat, lentils, garbanzo beans, dry peas, and canola. To determine the spatial distribution of theoretical foodsheds in the region, production zones of $2 \times 2 \mathrm{~km}$ in size were constructed, which were considered a convenient unit for estimating production capacity (Figure 2). These zones served as appropriately sized supply centers for major cities or towns where food hubs or farmers' markets are located when distribution distances are considered.
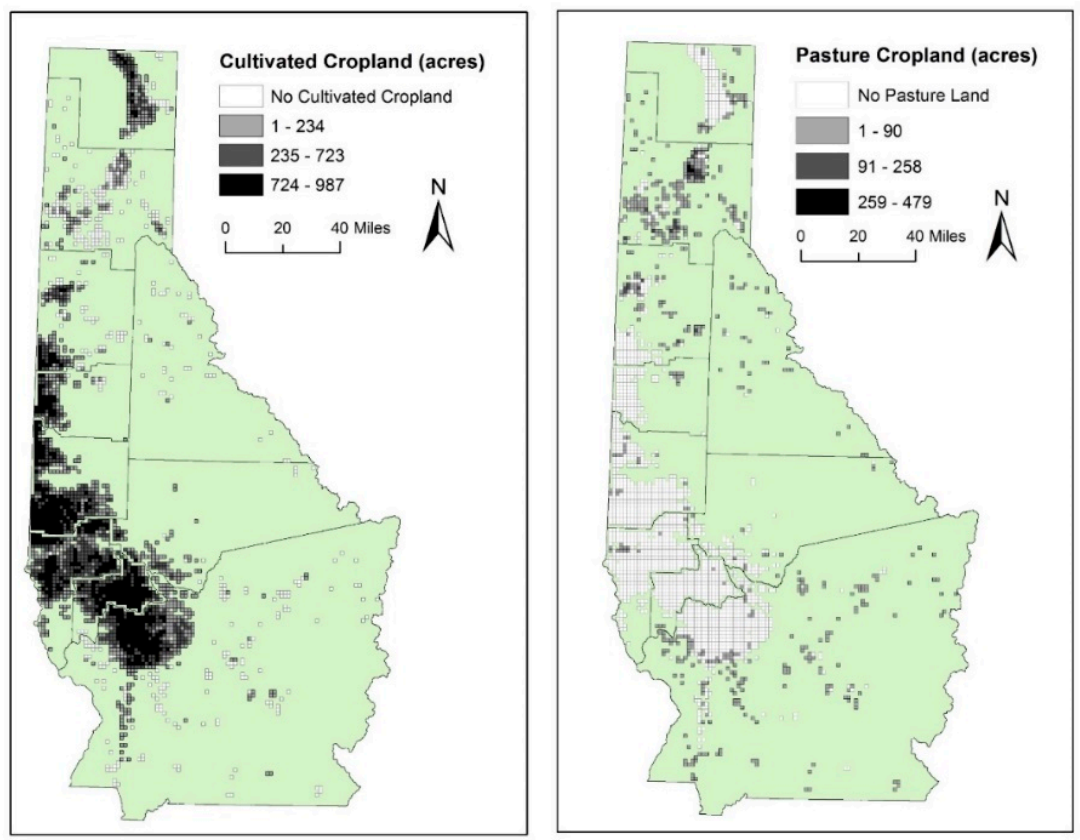

Figure 2. Two-kilometer production zones displaying the current distribution of cultivated and pasture lands in Northern Idaho. 


\subsection{Spatial Optimization, Spatial Analysis and Modeling, and Alternative Scenarios}

A potential foodshed was constructed in a theoretical manner based on a number of assumptions. First, the model estimated how much acreage would be necessary to provide food locally to supply population centers in Northern Idaho. The population size based on the 2010 U.S. census was used to determine maximum possible consumption. Second, the geographical extents of foodsheds in this work were limited to Idaho due to differences in data availability and policy implications for regional food system planning. Foodshed models also assume that cultivated and pasture lands are the primary cropland types and pasture land is mainly used to supply livestock feeds, although forestland and grassland are currently used for grazing or forage supply in the region.

A foodshed optimization problem was solved using linear programming. The optimization problem to be solved was focused on supplying the food needs of major population centers in Northern Idaho while minimizing the food distance travelled between supply and demand [23]. As shown in Equations (1)-(4), $C=\left\{C_{i j}\right\}$ denotes the distance between the production zone $(i)$ and the demand point (j). Longitude and latitude coordinates were employed to calculate the distance under the assumption that the transportation routes follow a north-south road grid. $\mathrm{X}=\left\{x_{i j}\right\}$ denotes the supply from each production zone (i) to the demand point or population center $(j)$. This problem was subject to two constraints: the food supplied must be greater than the need for the region $\left\{d_{j}\right\}$ and less than or equal to land availability and expected yields of each crop $\left\{s_{i}\right\}$ in each production zone.

Minimize

$$
\sum_{i=1}^{S} \sum_{j=1}^{D} C_{i j} x_{i j}
$$

Subject to

$$
\begin{gathered}
\sum_{i=1}^{s} x_{i j} \geq d_{j} \\
\sum_{i=0}^{n} x_{i j} \leq s_{i} \\
x_{i j} \geq 0
\end{gathered}
$$

Besides spatial optimization, we also carried out a spatial analysis of current local food producers' locations and incorporated spatial determinants of existing local food producers into the optimization modeling. To do this, existing local food producers were firstly geocoded. This data is available through a number of different sources, including commercial websites (e.g., localharvest.org) and the Idaho State Department of Agriculture, which provided a list of organic certified local food producers in Idaho. Secondly, we validated their addresses and checked their locations through the end of 2016. In total, 133 active local food producers were identified, and this information was further linked to agricultural production zones to identify the zones with a presence of local food production. Thirdly, a logistic regression analysis was carried out to compare a variety of biophysical characteristics of production zones, including soil characteristics, precipitation, steepness, and locational characteristics such as distance to cities and towns, with the presence of local food production in Northern Idaho to other randomly-chosen agricultural production zones in the region without the presence of these types of agricultural production activities.

Our logistic regression had the following general form:

$$
\operatorname{Logit}(\mathrm{Y})=\beta_{0}+\sum_{i=1}^{n} \beta_{i} x_{i}+e
$$

where $x_{i}$ denotes the observation on various soil and the locational characteristics of the current locations of local food producers (as described in greater detail in the rest of the article). The results 
of our logistic regression were converted into a likelihood function with 1 being the highest and 0 the lowest. The probability estimates were then applied to all the $2 \times 2 \mathrm{~km}$ production zones using similar variables. We integrated the probability or suitability scores into the food-distance function mentioned earlier in the optimization exercise. For each production zone, the food distance traveled was multiplied by the probability derived from the logistic regression.

An alternative land-use scenario was developed to explore the ecological benefits of local food production in the northern Idaho region. Based on the preliminary analysis of land supply and demand in the region, a shortage of pastureland for growing feeds exists in the area and current livestock production relies on feed from other areas. Additionally, the Palouse region in the southern part of Northern Idaho is historically famous for soil erosion $[25,26]$. Hence, converting a portion of cropland used for annual cultivation to perennial agriculture or pasture would be beneficial to reducing soil erosion. In this work, two indices including soil erodibility (SE) and crop productivities (CPI) were employed when converting annually cultivated cropland to pasture. The CPI index was developed by the Natural Resource Conservation Service (NRCS) to represent a rating of potential yield of one soil against another [8]. The highest CPI score is 1, indicating the most productive soil. The soil erodibility score follows the same scheme in that the highest score is given to lands associated with a high risk of soil erosion due to water and/or wind. In the model, lands where the CPI was under 0.3 were intersected with areas that had SE scores above 0.3 to represent not only low-productivity lands but lands that would also suffers from the risk of erosion.

\section{Results and Discussion}

\subsection{Growing Demand for Local Food}

Table 3 illustrates the desire for different groups of local food in Northern Idaho. Respondents or local buyers are clearly interested in sourcing local food products. Vegetables and fruits stand out as the most desired products in the region, followed by dairy/meat/eggs. Twenty-eight of the respondents sourced vegetables locally, and nearly half of the respondents were interested in sourcing vegetables from local producers (Table 3). Thirty-four percent of respondents reported they sourced small-plant fruits such as berries from local producers and $47 \%$ were interested in sourcing tree fruits locally. More than $30 \%$ of the surveyed buyers indicated they had been sourcing or were interested in sourcing dairy products locally. Additionally, over $80 \%$ of buyers reported that they were in favor of fresh products, while $20 \%$ indicated they preferred canned and processed foods. Clearly, in conjunction with rapid population growth, there has been a growing demand for local food in Northern Idaho. In this regard, a foodshed model was used to gauge whether agricultural capacity at the regional level could theoretically meet this rising demand in this case and to better understand the local food production capacity with respect to land resources [7].

Table 3. Northern Idaho grocery and restaurant buyer survey results. $\mathrm{N}=40$.

\begin{tabular}{ccccc}
\hline Product & $\begin{array}{c}\text { Does NOT Source This } \\
\text { Product, but is Interested in } \\
\text { Sourcing it Locally }\end{array}$ & $\begin{array}{c}\text { Sources This } \\
\text { Product } \\
\text { Locally }\end{array}$ & $\begin{array}{c}\text { Sources This Product, } \\
\text { but is NOT Interested } \\
\text { in Sourcing it Locally }\end{array}$ & $\begin{array}{c}\text { Does NOT Source This Product, } \\
\text { and is NOT Interested in } \\
\text { Sourcing it Locally }\end{array}$ \\
\hline Vegetables & $49.33 \%$ & $26.81 \%$ & $3.26 \%$ & $20.59 \%$ \\
Small Plant Fruits & $38.71 \%$ & $34.10 \%$ & $6.45 \%$ & $20.74 \%$ \\
Tree Fruits & $47.18 \%$ & $26.06 \%$ & $2.82 \%$ & $23.94 \%$ \\
Dairy, Meat, \& Eggs & $32.06 \%$ & $33.10 \%$ & $5.57 \%$ & $29.27 \%$ \\
Field Crops/Grains & $21.30 \%$ & $28.40 \%$ & $2.96 \%$ & $47.34 \%$ \\
\hline
\end{tabular}

\subsection{The Geography of Current Local Food Production}

Figure 3 depicts the geography of the current food production locations in Northern Idaho. Although most of the prime farmland is concentrated in a swath of Northern Idaho along the Washington state border, small and local producers are not concentrated in this prime farmland, which is dominated by commodity production. They instead occupy smaller tracts of land in areas typically 
relatively close to larger resort towns, such as Coeur d'Alene, Sandpoint, and Bonners Ferry in the north (Figure 3). The counties where local food producers are concentrated do not correlate at all with those where the majority of farmland is located; it appears that local food producers tend to locate in smaller parcels of discontinuous suitable land.

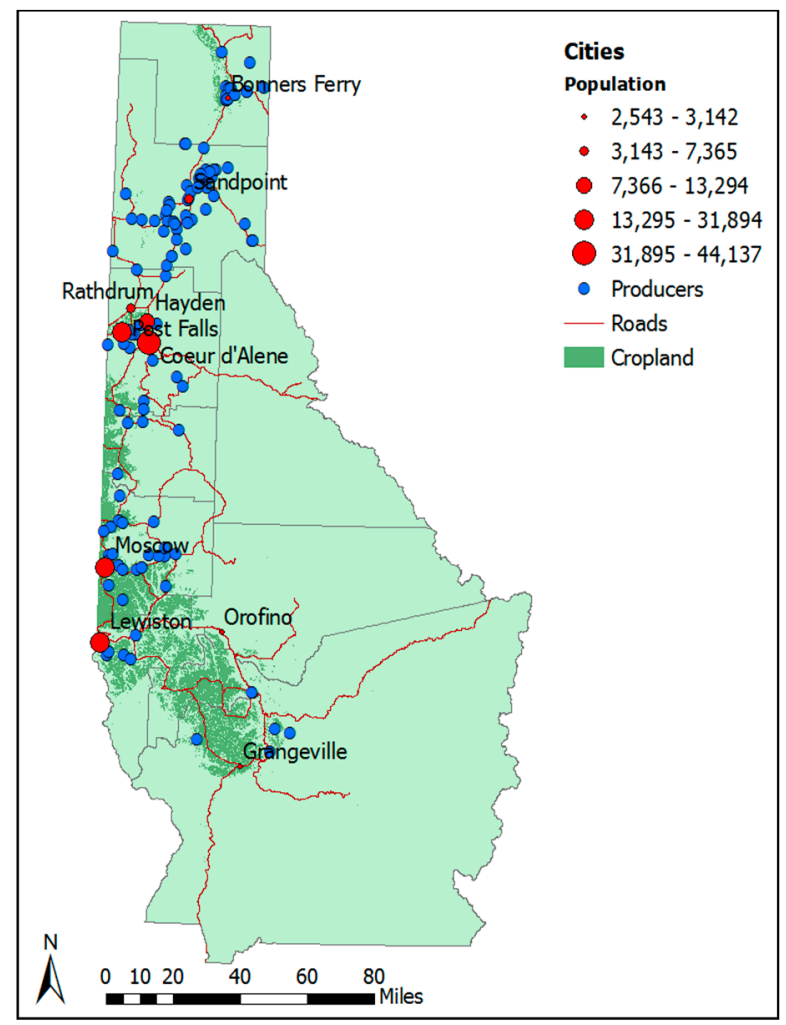

Figure 3. Locations of Local Food Producers in Northern Idaho.

From the dataset of 133 local food producers, the different products were classified into different groups (Figure 4). Proximity to populated towns was most marked for vegetables, whereas fruit had a more even distribution along the U.S. 95 corridor that forms the economic spine of Northern Idaho, with meats between vegetables and fruits. Poultry/eggs and dairy tend to cluster closer to populated areas. As also shown in the Figure 4, fruits were grown close to the market, whereas livestock were raised farther out, peaking at 10-20 miles from the market.

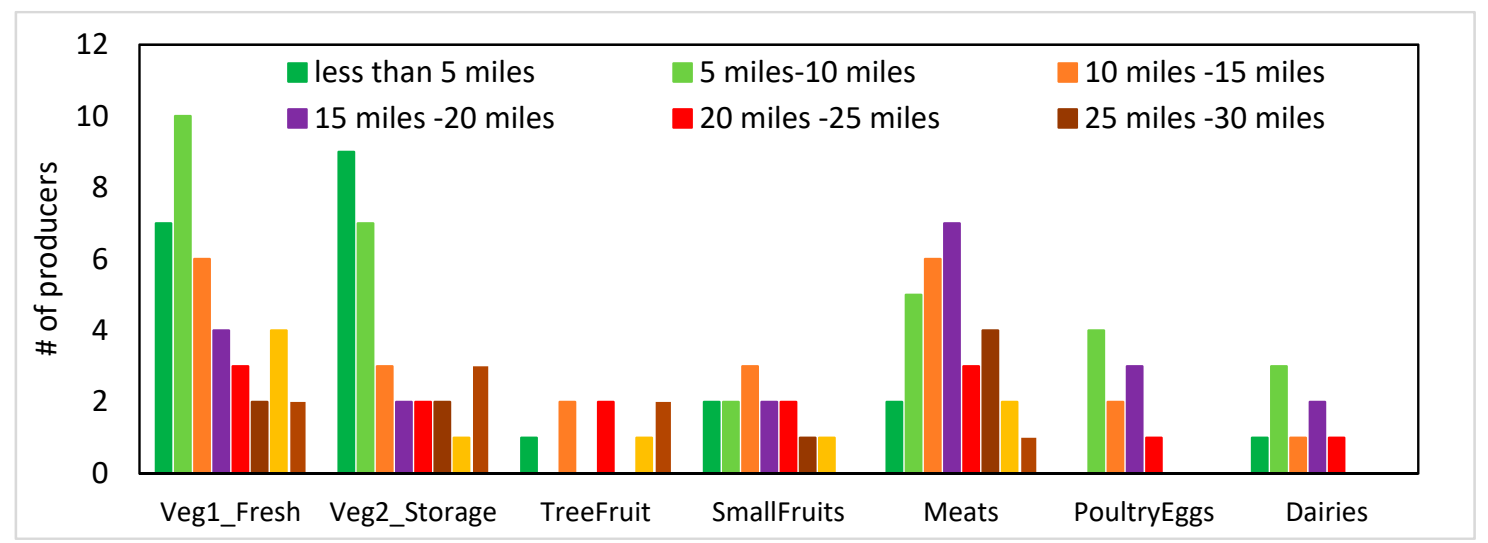

Figure 4. Numbers of farms by product type and distance to nearest cities (in the unit of miles). Source: Local harvest.org and Idaho State Department of Agriculture. 
The results of the logistic regression further unfold the spatial or locational determinants of local food production compared to conventional agriculture (see Table 4). Most of the factors increased the probability of being used for local food production, including having a higher soil water capacity and smaller distances from major cities. Specifically, increased soil coarseness indicates high-quality farmland; this indicates that local food production tends to locate on more productive soil.

Table 4. Spatial determinants of local food producers' locations.

\begin{tabular}{cccc}
\hline Independent Variables & Description & Coeff. & P-value \\
\hline (Intercept) & Soil water capacity (vol. fraction) with & -0.184 & 0.992 \\
Water capacity & FC = pF 2.0 at surface & $0.225^{* *}$ & 0.080 \\
precipitation & Annual precipitation, mm & $-4.775 \times 10-3$ & 0.079 \\
slope & Slope, in degrees & $-0.074^{* *}$ & 0.028 \\
soil depth & Absolute depth to bedrock, cm & $-3.069 \times 10^{-4}$ & 0.118 \\
soil fragments & Coarse soil fragments, \% of volume & $-0.066^{* * *}$ & 0.006 \\
soil pH & Soil pH $\times 10$ & -0.038 & 0.337 \\
temperature & Mean annual temperature, ${ }^{\circ} \mathrm{C} \times 10$ & -0.021 & 0.289 \\
to cities & To nearest cities or urban areas, kilometer & $-1.830 \times 10^{-2 * * *}$ & 0.001 \\
to highway & Road distance, kilometer & $-0.739 \times 10^{-2}$ & 0.186 \\
\hline
\end{tabular}

Significance codes: $0^{* * * *} 0.001^{\star * * \prime} 0.01^{\star * \prime} 0.05$ '! $0.1^{\prime \prime}$ ' 1; ROC: $69.8 \%$; Note: Soil depth, fragments, $\mathrm{pH}$, and water capacity were obtained from the ISRIC soil data hub. Annual precipitation and temperature raster were obtained from WorldClim, and slope was calculated from two DEMs obtained from the Inside Idaho website (https://www.insideidaho.org/).

\subsection{Foodsheds and Land Use Scenarios}

The analysis of yield data and USDA's ideal diet indicates that each person in the region would require 0.15 ha ( 0.38 acre) of cultivated land per year and 0.22 ha ( 0.56 acre) of pasture land, slightly under 0.4 ha or 1 acre per year per person. In 2011, the region had more than 369,952 ha of cultivated cropland and only 6104 ha of pasture. Therefore, the region should have plenty of agricultural land to support the population of 317,752 (Table 5). However, there has been a shortage of pasture land due to the demand for HNEp; a total of 71,442 ha of pasture is needed but the current available pasture is around 6104 ha.

Table 5. Demand of agricultural land and the land available to meet this demand for cultivated foodsheds (HNEa) and pasture foodsheds (HNEp).

\begin{tabular}{cccc}
\hline Food Category & Land Requirements (ha) & Land Supply (ha) & Production Potential (Mg) \\
\hline HNEa & 48,577 & 369,952 & $4,777,631$ \\
HNEp & 71,442 & 6104 & 20,832 \\
HNEt & 120,020 & 376,057 & $4,798,462$ \\
\hline
\end{tabular}

Source: Agricultural census, 2012; NASS, quick statistics; ID agricultural bulletin.

Figure 5 shows the spatial extent of local foodsheds. We found that proximity to the populated towns was most marked for cultivated agriculture, whereas perennial agriculture or pasture foodshed had a more even distribution along the U.S. 95 corridor. Specifically, there was a great potential for local food production, with a particular focus on annually cultivated agriculture, in areas closer to the cities of Coeur d'Alene, Post Falls, and Sandpoint. Likewise, in Latah County, where Moscow is located, although current local food production most often occupies the edges of the major agricultural region where the land is still arable. New potential production zones could be located as close as possible to Moscow, especially if the farms concentrate on producing vegetables and fruits. 

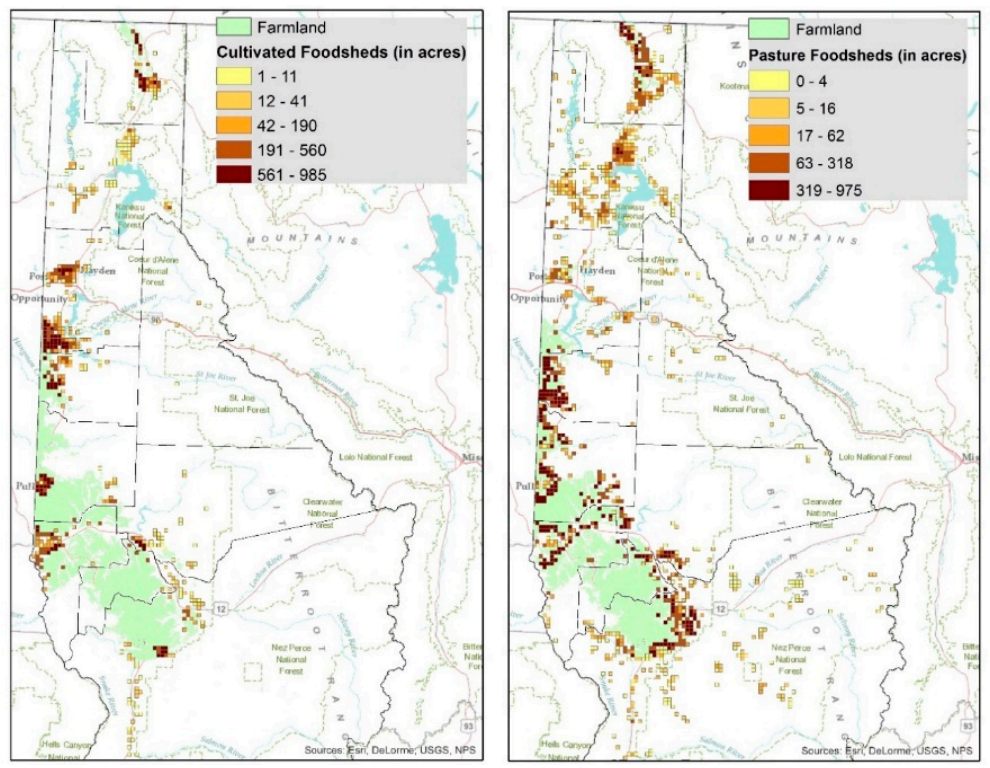

Figure 5. Theoretical cultivated and pasture foodsheds in Northern Idaho.

Table 6 further illustrates the results of both the baseline model and the alternative land use scenario with an emphasis on land conservation and the soil erosion. The results of the optimization indicate that cities in the northern part had the longest food distances to meet demand compared to the foodsheds centered on smaller-size towns in the southern part of the region, which boasts part of the Palouse agricultural region. Resort towns such as Coeur d'Alene and Sandpoint have attracted new residents for their natural amenities including lakes and mountains. As compared to cultivated foodsheds centered on Moscow and Lewiston, the size of the foodsheds centered on the Coeur d'Alene-Post Falls area incorporates areas farther away (Figure 5). For example, for those areas in proximity to the cities of Coeur d'Alene and Post Falls, the average unit of food derived from annual cropping (e.g., vegetables and fruits) would travel up to 32 miles (or $51 \mathrm{~km}$ ) and 19 miles (or $30 \mathrm{~km}$ ) to reach the demand point, as compared to 2.55 miles (or $4.07 \mathrm{~km}$ ) in the case of the foodshed centered on Moscow and 3.89 miles (or $6.26 \mathrm{~km}$ ) in the case of Lewiston (Table 6).

Table 6. Food distance travelled by population centers (in the unit of km).

\begin{tabular}{ccccccc}
\hline \multirow{2}{*}{ Population Center(s) } & \multicolumn{2}{c}{ Total } & \multicolumn{2}{c}{ Cultivated Foodshed } & \multicolumn{2}{c}{ Pasture Foodshed } \\
\cline { 2 - 6 } & Baseline & Alternative & Baseline & Alternative & Baseline & Alternative \\
\hline Coeur d'Alene & 90.31 & 118.43 & 51.46 & 50.63 & 116.72 & 164.52 \\
Post Falls & 82.70 & 152.06 & 29.52 & 29.35 & 118.86 & 235.48 \\
Lewiston & 7.43 & 25.32 & 6.26 & 6.44 & 8.22 & 7.69 \\
Moscow & 6.23 & 48.49 & 4.07 & 4.07 & 50.54 & 171.64 \\
Sandpoint & 56.12 & 128.76 & 64.32 & 65.70 & 62.47 & 131.66 \\
All zones & 49.29 & 90.43 & 29.91 & 29.79 & & \\
\hline
\end{tabular}

The alternative scenario of removing less productive, highly erodible lands further suggests interesting connections between local food systems and farmland or soil conservation. Under the alternative scenario, the total distance each unit of food needs to travel increases from 30.63 miles (or $49.29 \mathrm{~km}$ ) to 56.19 miles (or $90.43 \mathrm{~km}$ ), a rise of $183 \%$ (Table 6). However, as marginal cropland on erodible soils is converted from annual cropping to perennial agriculture, some additional benefits of growing local food can be generated by exploring the agricultural land surplus in the region [8]. This is more likely in the areas of the Palouse region, which is characterized by the concentration of eroded soils. 


\section{Conclusions}

This study supports both the body of research suggesting a robust and growing demand for food products sourced locally, especially vegetables [27], as well as research that supports the potential to locally-source enough produce to support the population of Northern Idaho [11,12]. The results from our optimization exercise in Northern Idaho indicate that local food production, especially that related to perennial agriculture, can provide an alternative way to use agricultural land that may otherwise be suffering from soil erosion.

The intermediated buyer survey indicates that the demand for local foods, especially for most vegetables and many fruits, is quite high. This suggests that local food producers should concentrate on those selected vegetables and fruits. The demand for local sourcing of other categories of food is more mixed, but there are certain items which are in high demand for local sourcing, including beef, eggs, honey, bread, dairy, and dry peas and lentils. These results provide some nuanced evidence of the attraction of different local food products, which demonstrates that local food is a niche but also a diverse market. Due to the limited number of survey respondents and the lack of inclusion of institutional buyers such as hospitals and school districts, additional intermediated buyer research is needed to better quantify intermediated market demand for local food products in Northern Idaho.

The results of the spatial analysis and modeling characterize the locational attributes of local food producers, supplying key information for the subsequent foodshed analysis. The results of our logistics regression indicate that current producers tend to be located on productive cropland and in the urban fringe. This is particularly true for areas in the vicinities of resort towns in the northern part of the region where farmland prices have skyrocketed in recent years. The cropland in the region should be enough to sustain the whole population in Northern Idaho within an average distance of 30.44 miles ( or $49 \mathrm{~km}$ ) in the context of the Mountain West, which corroborates the result of the prior study of New York State [9], which has somewhat similar moderately rugged terrain and climatic conditions to Northern Idaho. Additionally, when considering perennial agricultural activities centered on local food, possible ecological benefits can be derived from converting farmland cultivated annually to pasture [8], in spite of longer food distances travelled. We argued that in this case, the transport costs or environmental costs associated with food distances may be less important than soil erosion benefits in the Palouse region. Land use policy that promotes the conversion of highly erodible cropland from dryland agriculture production to pasture could be linked to additional benefits derived from locally grown food and small farming, which have been found to have strong socioeconomic impacts in recent studies $[21,28]$.

The main limitation of the study is that it only considered the suitability of existing agricultural land for local food production. The conversion of agricultural land to other land uses has been a key challenge for local food production with respect to land access, given rising farmland values and the issue of farmland ownership $[29,30]$. In addition, land use scenarios or land consumption could be overestimated if per-hectare yields increase due to improved production methods and efficiencies. Furthermore, soil erodibility was emphasized in the present study as an environmental attribute. It is important to consider the loss of wildlife habitat, water quality, carbon sequestration, and other ecological and social impacts and benefits of land conversion to local food production when relevant data is available. Future research directions could also include infrastructure available and needed for local food processing and distribution, the economic impacts of increasing local food sales in urban areas along the Washington-Idaho border (Clarkston, Pullman, Spokane and Spokane Valley specifically), and the interest and willingness of land owners to convert land from export-oriented dryland agriculture production to producing local food for local markets.

Author Contributions: Coauthor's contributed to individual portions of the research as follows: conceptualization, F.L., C.D., and D.S.; methodology, F.L., and B.G.; software, F.L., B.G., W.F.; validation, F.L., B.G., C.D., and C.F.; formal analysis, F.L., B.G., and W.F.; investigation, F.L.; resources, F.L., C.D., and D.S.; data curation, F.L., C.D., B.G.; writing-original draft preparation, F.L., B.G.; writing-review and editing, F.L., B.G., C.D., D.S., C.F.; visualization, 
F.L., B.G., W.F.; supervision, F.L., D.S.; project administration, F.L., D.S.; funding acquisition, F.L., C.D., D.S., and C.F.

Funding: This research was supported by the USDA National Institute of Food and Agriculture (USDA-NIFA) under grant no. 2014-68006-21866 and no. 2018-68006-28102 and from the Agriculture and Food Research Initiative.

Acknowledgments: We thank Soren Newman, Jodi Johnson-Maynard, Ray Dezzani, Shenghan Xu, and Li Huang for their contributions; we also thank project advisors who were involved in the above-mentioned food-system related projects in Idaho supported by USDA-NIFA.

Conflicts of Interest: The authors declare no conflict of interest. The funders had no role in the design of the study; in the collection, analysis, or interpretation of data; in the writing of the manuscript, or the decision to publish the results.

\section{References}

1. Low, S.A.; Adalja, A.; Beaulieu, E.; Key, N.; Martinez, S.; Melton, A.; Suttles, S. Trends in US Local and Regional Food Systems: Report to Congress; United States Department of Agriculture, Economic Research Service: Washington, DC, USA, 2015.

2. Martinez, S.W. Policies Supporting Local Food in the United States. Agriculture 2016, 6, 43. [CrossRef]

3. Greene, C.; Hitaj, C.; Bowman, M.; Cooke, B.; Ferreira, G.; Carlson, A.; McBride, W. The Outlook for Organic Agriculture; United States Department of Agriculture, Economic Research Service: Washington, DC, USA, 2018.

4. Erickson, D.L.; Lovell, S.T.; Méndez, V.E. Identifying, quantifying and classifying agricultural opportunities for land use planning. Landsc. Urban Plan. 2013, 118, 29-39. [CrossRef]

5. Saha, M.; Eckelman, M.J. Growing fresh fruits and vegetables in an urban landscape: A geospatial assessment of ground level and rooftop urban agriculture potential in Boston, USA. Landsc. Urban Plan. 2017, 165, 130-141. [CrossRef]

6. Mack, E.A.; Tong, D.; Credit, K. Gardening in the desert: a spatial optimization approach to locating gardens in rapidly expanding urban environments. Int. J. Heal. Geogr. 2017, 16, 37. [CrossRef] [PubMed]

7. Peters, C.J.; Bills, N.L.; Lembo, A.J.; Wilkins, J.L.; Fick, G.W. Mapping potential foodsheds in New York State by food group: An approach for prioritizing which foods to grow locally. Renew. Agric. Food Syst. 2012, 27, 125-137. [CrossRef]

8. Galzki, J.C.; Mulla, D.J.; Peters, C.J. Mapping the potential of local food capacity in Southeastern Minnesota. Renew. Agric. Food Syst. 2015, 30, 364-372. [CrossRef]

9. Peters, C.J.; Bills, N.L.; Lembo, A.J.; Wilkins, J.L.; Fick, G.W. Mapping potential foodsheds in New York State: A spatial model for evaluating the capacity to localize food production. Renew. Agric. Food Syst. 2009, 24, 72-84. [CrossRef]

10. Dundar, B.; Costello, C.; McGarvey, R.G. Robust optimization evaluation of reliance on locally produced foods. Environ. Syst. Decis. 2017, 37,34-41. [CrossRef]

11. Horst, M.; Gaolach, B. The potential of local food systems in North America: A review of foodshed analyses. Renew. Agric. Food Syst. 2015, 30, 399-407. [CrossRef]

12. Zumkehr, A.; Campbell, J.E. The potential for local croplands to meet US food demand. Front. Ecol. Environ. 2015, 13, 244-248. [CrossRef]

13. Nolasco, C.; Soler, L.; Freitas, M.; Lahsen, M.; Ometto, J.; Nolasco, C.L.; Ometto, J.P.H.B. Scenarios of Vegetable Demand vs. Production in Brazil: The Links between Nutritional Security and Small Farming. Land 2017, 6, 49. [CrossRef]

14. Karg, H.; Drechsel, P.; Akoto-Danso, E.K.; Glaser, R.; Nyarko, G.; Buerkert, A. Foodsheds and City Region Food Systems in Two West African Cities. Sustainability 2016, 8, 1175. [CrossRef]

15. Zasada, I.; Schmutz, U.; Wascher, D.; Kneafsey, M.; Corsi, S.; Mazzocchi, C.; Piorr, A. Food beyond the city -Analysing foodsheds and self-sufficiency for different food system scenarios in European metropolitan regions. City Culture Soc. 2017, 16, 25-35. [CrossRef]

16. Augstburger, H.; Käser, F.; Rist, S. Assessing Food Systems and Their Impact on Common Pool Resources and Resilience. Land 2019, 8, 71. [CrossRef]

17. Galzki, J.C.; Mulla, D.J.; Meier, E. Mapping Potential Foodsheds Using Regionalized Consumer Expenditure Data for Southeastern Minnesota. J. Agric. Food Syst. Community Dev. 2017, 7, 181-196. [CrossRef]

18. University of Idaho. Taking the Long View in Northern Idaho; University of Idaho: Post Falls, ID, USA, 2008. 
19. Idaho Department of Labor. 2017 Idaho Labor Market and Economic Report; Idaho Department of Labor: Boise, ID, USA, 2018.

20. Watson, P.; Cooke, S.; Kay, D.; Alward, G.; Morales, A. A Method for Evaluating the Economic Contribution of a Local Food System. J. Agric. Resour. Econ. 2017, 42, 180-194.

21. Bauman, A.; DePhelps, C.; McFadden, D.T. Assessing a Local Food System: The Palouse-Clearwater Food Coalition Assessment Process. J. Agric. Food Syst. Community Dev. 2019, 8, 107-118. [CrossRef]

22. DePhelps, C.; Ussery, C.J.; Liang, B. Taste of Home: Local Food in the Palouse-Clearwater Region. 2019. Available online: https://uidaho.maps.arcgis.com/apps/Shortlist/index.html?appid=60e504889402405f9df00bdecbd766e9 (accessed on 30 July 2019).

23. Hu, G.; Wang, L.; Arendt, S.; Boeckenstedt, R. An optimization approach to assessing the self-sustainability potential of food demand in the Midwestern United States. J. Agric. Food Syst. Community Dev. 2011, 2, 195-207. [CrossRef]

24. Hu, G.; Wang, L.; Arendt, S.; Boeckenstedt, R. Analyzing Sustainable, Localized Food Production Systems With a Systematic Optimization Model. J. Hunger. Environ. Nutr. 2011, 6, 220-232. [CrossRef]

25. Black, A.E.; Strand, E.; Wright, R.; Scott, J.; Morgan, P.; Watson, C. Land use history at multiple scales: implications for conservation planning. Landsc. Urban Plan. 1998, 43, 49-63. [CrossRef]

26. Cox, D.; Bezdicek, D.; Fauci, M. Effects of compost, coal ash, and straw amendments on restoring the quality of eroded Palouse soil. Boil. Fertil. Soils 2001, 33, 365-372. [CrossRef]

27. Feldmann, C.; Hamm, U. Consumers' perceptions and preferences for local food: A review. Food Qual. Prefer. 2015, 40, 152-164. [CrossRef]

28. Saul, D.A.; Newman, S.M.; Lee, T.; Peterson, S.; Devadoss, S.; Shrestha, D.S.; Sanyal, N. Increasing Prosperity for Small Farms Through Sustainable Livestock Production, Processing, and Marketing. J. Agric. Food Syst. Community Dev. 2016, 5, 21-37. [CrossRef]

29. Horst, M. Changes in Farmland Ownership in Oregon, USA. Land 2019, 8, 39. [CrossRef]

30. Horst, M.; Gwin, L. Land access for direct market food farmers in Oregon, USA. Land Use Policy 2018, 75, 594-611. [CrossRef]

(C) 2019 by the authors. Licensee MDPI, Basel, Switzerland. This article is an open access article distributed under the terms and conditions of the Creative Commons Attribution (CC BY) license (http://creativecommons.org/licenses/by/4.0/). 